\title{
Tumor Necrosis Factor-a Polymorphism in Helicobacter Pylori Associated Gastric Carcinoma
}

\author{
Barua $\mathrm{RR}^{1^{*}}$, Barua $\mathrm{S}^{2}$, Barua $\mathrm{HR}^{3}$, Barua $\mathrm{AK}^{4}$, Ansari $\mathrm{MAJ}^{5}$, Chong $\mathrm{JM}^{6}$, Uozaki $\mathrm{H}^{7}$, Fukayama $\mathrm{M}^{7}$ \\ ${ }^{1}$ Department of Pathology, Dr. Sirajul Islam Medical College, Dhaka, Bangladesh; ${ }^{2}$ Departmentof \\ Medicine, Dhaka Medical College, Dhaka, Bangladesh; ${ }^{3}$ Department of Obstetric and Gynaecology, \\ Rangamati Medical College, Rangamati, Bangladesh; ${ }^{4}$ Bandarban District Hospital, Bandarban, \\ Bangladesh; ${ }^{5}$ Department of Endocrinology, Dhaka Medical College, Dhaka, Bangladesh; \\ ${ }^{6}$ Department of Pathology, Tokyo Metropolitan Toshima Hospital, Tokyo, Japan; ${ }^{7}$ Department of \\ Pathology, The University of Tokyo, Tokyo, Japan.
}

\begin{abstract}
Background: Gastric cancer (GC) is the leading cause of cancer death in the world. Chronic inflammation is a predisposing factor of gastric carcinogenesis. TNF- $\alpha$ is a key pro-inflammatory cytokine secreted by macrophages and causes development of malignant diseases. It also plays an important role in chronic inflammation caused by Helicobacter Pylori. Therefore, TNF- $\alpha$ polymorphisms is studied in Helicobacter Pylori infected gastric cancer.
\end{abstract}

Objective: To find out the high risk group of Helicobacter Pylori infected gastric cancer cases in Asian and Caucasian people.

Methods: A total of $130 \mathrm{GC}$ cases and 103 healthy controls from Jichi Medical School, Japan were studied. TNF- $\alpha$ genotype and allele frequency were studied by Restriction Fragment Length Polymorphism (RFLP).

Results: Among the study population TNFa-308A was less frequent in Asian people than those of Caucasian. TNFa-238G allele was more frequent in $\mathrm{H}$. pylori positive $\mathrm{GC}(p<0.036)$ cases.

Conclusion: Findings of the study suggest that TNF-238G polymorphism of TNF- $\alpha$ gene may be closely associated with susceptibility to Helicobacter Pylori infected gastric cancer in Asian patients. This might be due to high cytokine production by TNF-238G allele.

Keywords: Tumor necrosis Factor- $\alpha$, Helicobactor pylori, Gastric carcinomas, Polymorphism

\section{Introduction}

Gastric cancer (GC) is the leading cause of cancer death in the world. Chronic inflammation is known to be a predisposing factor of carcinogenesis of GC; therefore, high cytokine production may promote the development of cancer. Single-nucleotide polymorphisms (SNPs) located within the regulatory regions of cytokine genes may result in individual variations of cytokine expression. Among the cytokines; TNF- $\alpha$ and IL10 have complex and opposing role in inflammation and immunity. Helicobacter pylori $(H$. pylori) infection plays a crucial role in gastric cancer pathogenesis. ${ }^{1-2}$ Persistent inflammation caused by H. pylori infection induces hypochlorhydria and gastric atrophy, which are two early precursors of gastric cancer development. Genetic variations in genes encoding cytokines and their receptors, which determine the intensity of the

Correspondence: Dr. Rita Rani Barua, Department of Pathology, Dr. Sirajul Islam Medical College, 12/3, New Circular Road, Malibagh, Dhaka, Bangladesh; e-mail: baruarita@yahoo.com; inflammatory response to the bacteria, may contribute to individual differences in severity of outcome of $\mathrm{H}$. pylori infection and progression of gastric lesions ${ }^{3}$. TNF- $\alpha$ is over-expressed in patients with H. pylori infection. $^{2}$

TNF- $\alpha$ is a proinflammatory cytokine and implicated in the severity of different immuneregulated diseases including autoimmune diseases and transplantation. TNF- $\alpha$ gene is located on chromosome 6p21.3 and contains a large number of polymorphisms. TNF $\alpha-308 \mathrm{~A}$ is found to be related to overall survival in non-Hodgkin's lymphoma and TNF $\alpha-308$ alleles are associated with chronic lymphocytic leukemia ${ }^{4}$.Some groups reported that TNF $\alpha-308 \mathrm{~A}$ allele has higher transcriptional activity compared with the $-308 \mathrm{G}$ allele. ${ }^{5-6}$ The TNF $\alpha-238$ alleles have shown conflicting results. One group has reported $-238 \mathrm{G}$ allele was associated with higher TNF $\alpha$ production. ${ }^{7}$ It was examined 2 loci of TNF- $\alpha$ promoter; TNFa-308 and -238 in this study to find out the high risk group. 


\section{Materials and Methods}

Patients and tissues / blood: The authors used 130 cases of GC, which had been surgically resected at Jichi Medical School Hospital from 1999-2000. Frozen tissues were taken from the carcinoma and non-neoplastic tissues. Minute and flat lesions were excluded from the study, but there was no other case selection. Blood samples were obtained from 103 healthy volunteers, which served as a control for the analysis of IL-10 and TNF- $\alpha$ polymorphism. This study was reviewed and approved by the Institute Ethics Committee of Jichi Medical School.

Immediately after resection of the stomach, normal tissues remote from the carcinomas were taken and frozen in dry ice acetone. The remaining tissue was routinely processed for histopathologic analysis with hematoxylin and eosin staining. The tumor location, depth of invasion, lymphatic or vascular invasion and lymph node metastasis were determined according to the general rules of the Japanese research Society for $\mathrm{GC}^{8}$. Histologic subtypes were classified according to Lauren as diffuse or intestinal. ${ }^{9}$ The clinicopathological data of the tumors and clinical data of healthy control also assessed (table 1-1(a) and table 1-1(b)).

DNA extraction:Genomic DNA was isolated from the non-neoplastic tissue and blood using DNeasy Tissue System (Qiagen, Inc., Valencia, USA), according to the manufacturer's instructions.

Determination of the infectious agents: $\mathrm{H}$. pylori infection in non-neoplastic gastric mucosa was determined by PCR targeting of the H. pylori urease A gene ${ }^{10}$.Urease A gene PCR amplified a $411 \mathrm{bp}$ fragment, using the following primers: 5'gccaatggtaaattagtt-3' and 5'-ctccttaattgttttac-3'. The PCR conditions were as follows: 30 cycles of $94 \mathrm{C}$ for $30 \mathrm{~s}, 45 \mathrm{C}$ for $90 \mathrm{~s}, 72 \mathrm{C}$ for $1 \mathrm{~min}$ followed by 10 cycles of $94 \mathrm{C}$ for 30 seconds, $45 \mathrm{C}$ for $90 \mathrm{~s}$, and $72 \mathrm{C}$ for $90 \mathrm{~s}$. PCR products were analyzed by electrophoresis on $2 \%$ agarose gel stained with ethidium bromide.

Evaluation of polymorphisms by PCR-RFLP:TNF $\alpha$ (TNF $\alpha-308,-238$ ) promoter polymorphisms were analyzed with PCR amplification followed by restriction fragment length polymorphism (RFLP). Two alleles, $A$ and $\mathrm{G}$, exist in both positions.

Polymorphisms of TNF- $\alpha$ :Nested PCR amplified a $118 \mathrm{bp}$ fragment including the polymorphic sites at positions -308 and -238 in the TNF- $\alpha$ promoter from the template genomic DNA. The primers
TNFa-P1 (5'-gaaggaaacaccacagac-3', position -372 to -353) and TNFa-P2 (5'-atctggaggaagcggtagtg-3', position -106 to -128) were used for the first round PCR and TNF-Nc (5'-aggcaataggttttcaggtccatg-3', position -332 to -309 ) and TNF-Bg (5'cacactccccatcctcccagagtc-3', position -215 to -237) for the second round. The underlined nucleotides of the primers indicate the mismatches, which were introduced to create restriction sites or minimize the duplex formation of primers. The reaction conditions for the first-round PCR were: $95 \mathrm{C}$ for 10 min; 35 cycles of $94 \mathrm{C}$ for $30 \mathrm{~s}, 57 \mathrm{C}$ for $30 \mathrm{~s}$, and $72 \mathrm{C}$ for $30 \mathrm{~s}$; and $72 \mathrm{C}$ for $5 \mathrm{~min}$. Two $\mu 1$ of the first round PCR products were used for the nested PCR product in a $25 \mu \mathrm{l}$ reaction volume under the same conditions, except that the annealing temperature was 55C. Four $\mu 1$ of the nested PCR products were digested overnight at $37 \mathrm{C}$ in a $10 \mu 1$ reaction volume containing 2.5 units of $N c o$ I to detect the -308 polymorphism and $B g l I I$ to detect the -238 polymorphism, and then analyzed on a $15 \%$ polyacrylamide gel (figure1). ${ }^{11}$

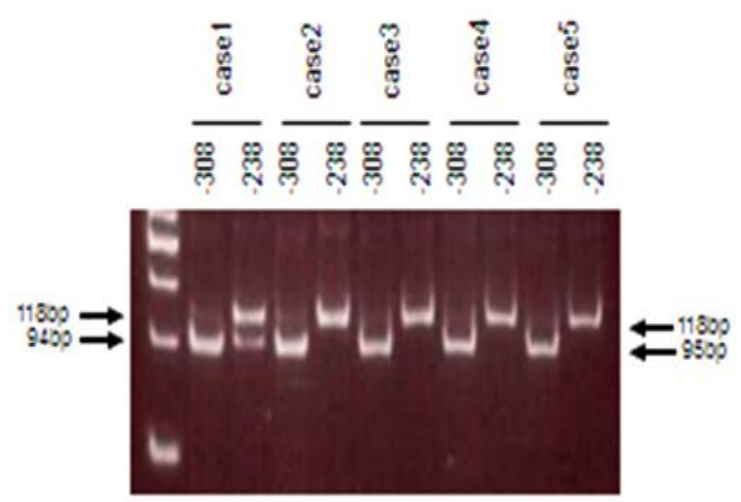

Figure 1: Analysis of TNF a promoter polymorphism by PCR-RFLP

Using the uniquely designed primer TNF-Bg in this study, both the -308 and -238 polymorphisms can be determined.

Data analysis: The frequency of genotypes was tested by chi-square.

\section{Results}

The clinicopathological data of the tumors and healthy control are summarized in (table I (a-b). Among the cancer cases male were predominant with average age $62.4 \pm 13.5$ years. Most of the tumors located in the upper part of stomach. Histopathologically, both the Japanese and Lauren classification adopted. 
Table I (a): Summary of the clinicopathological data of the examined gastric carcinomas

\begin{tabular}{lc}
\hline Tumors & 130 \\
Patients & 130 \\
H. Pylori positive GC/ H. Pylori & $98 / 29$ \\
negative GC & \\
Gender (male/female) & $85 / 45$ \\
Age (mean $\pm \mathrm{SD}$ ) & $62.4 \pm 13.5$ \\
Location (upper/middle/lower) & $27 / 68 / 35$ \\
Depth (m/sm/mp/ss/se/si) & $24 / 28 / 12 / 23 / 35 / 8$ \\
Early/Advanced & $52 / 78$ \\
Japanese GC classification & $16 / 29 / 24 / 48 / 11 / 12$ \\
(pap/tub1/tub2/por/sig/muc) & \\
Lauren classification & $70 / 60$ \\
(intestinal/diffuse) & \\
Lymphatic infiltration (p/n) & $92 / 38$ \\
Vessel infiltration (p/n) & $87 / 43$ \\
Lymph node metastasis & $63 / 67$ \\
\hline
\end{tabular}

P; Positive N; Negative

Table I (b): Clinical data of healthy control ( $\mathrm{n}=103)$

$$
\begin{array}{cc}
\text { Gender (male/female) } & 52 / 51 \\
\text { Age }(\text { mean } \pm \text { SD) } & 39.5 \pm 9.0
\end{array}
$$

Lymphovascular invasion was seen in most of the cases. Lymphnode metastases were observed in half of the cases. H. pylori infection was observed in 98 cases and the rest 29 were negative H. pylori. In control, male to female ratio was almost same with average age $39.5 \pm 9$ years.

Polymorphisms in this study and other studies: A total of 127 GC patients and 99 healthy controls were determined polymorphisms. Three GC patients and 4 healthy controls could not determine probably due to low quality of extracted DNA. The allele frequencies were performed in (table II).

Table II: Genotype and allele frequency in total gastric cancer and control

\begin{tabular}{lcl}
\hline & TNFa-308 & TNFa-238 \\
& GG/GA/AA G: A & GG/GA/AA G: A \\
\hline Gastric & $120 / 2 / 7$ & $123 / 2 / 2$ \\
cancer & $95 \%: 5 \%$ & $98 \%: 2 \%$ \\
Control & $101 / 2 / 0$ & $101 / 2 / 0$ \\
& $99 \%: 1 \%$ & $99 \%: 1 \%$ \\
\hline
\end{tabular}

No significant difference was found between the case and control. The distribution of TNF $\alpha-308 /-$ 238 polymorphisms in a control population together with other races data, which have been previously reported TNF $\alpha-308 \mathrm{G}$ was less frequent in Japanese than other Asians or Caucasians were also assessed (table III).

Polymorphisms frequency in GC patients and its comparison to other ethnics.

Table III: Allele frequencies of TNF- $\alpha$ in healthy control (This

\begin{tabular}{|c|c|c|c|c|}
\hline & Ethnicity & $\mathrm{N}$ & $\begin{array}{l}-308 \\
\text { G:A }\end{array}$ & $\begin{array}{l}-238 \\
\text { G:A }\end{array}$ \\
\hline This study & Japanese & 130 & $98 \%: 2 \%$ & $99 \%: 1 \%$ \\
\hline $\begin{array}{l}\text { Higuchi et } \\
\text { al; } 1998\end{array}$ & Japanese & 575 & $98.3 \%: 1.7 \%$ & $98 \%: 2 \%$ \\
\hline $\begin{array}{l}\text { Hashimoto } \\
\text { et al; } 2004\end{array}$ & Japanese & 458 & $99.2 \%: 0.8 \%$ & ND \\
\hline $\begin{array}{l}\text { Tsunemi } \\
\text { et al: } 2003\end{array}$ & Japanese & 96 & $97.9 \%: 2.1 \%$ & $99 \%: 1 \%$ \\
\hline $\begin{array}{l}\text { Wu et al; } \\
2002\end{array}$ & Taiwanese & 220 & $88 \%: 12 \%$ & $98 \%: 2 \%$ \\
\hline $\begin{array}{l}\text { Jang et al; } \\
2001\end{array}$ & Korean & 92 & $92.9 \%: 7.1 \%$ & $96.2 \%: 3.8 \%$ \\
\hline $\begin{array}{l}\text { Park et al; } \\
2002\end{array}$ & Korean & 190 & $84.7 \%: 15.3 \%$ & ND \\
\hline $\begin{array}{l}\text { Duan et al; } \\
2004\end{array}$ & Chinese & 632 & $92.9 \%: 7.1 \%$ & ND \\
\hline $\begin{array}{l}\text { El-Omar } \\
\text { et al; } 2003\end{array}$ & USA & 210 & $84.8 \%: 15.2 \%$ & ND \\
\hline $\begin{array}{l}\text { Reynard et } \\
\text { al; } 2000\end{array}$ & $\begin{array}{c}\text { U.K. } \\
\text { Caucasians }\end{array}$ & 76 & $78.3 \%: 21.7 \%$ & ND \\
\hline $\begin{array}{l}\text { Kurzawski } \\
\text { et al; } 2005\end{array}$ & $\begin{array}{c}\text { Polish } \\
\text { Caucasians }\end{array}$ & 205 & $85.1 \%: 14.9 \%$ & ND \\
\hline $\begin{array}{l}\text { Kurzawski } \\
\text { et al; } 2005\end{array}$ & $\begin{array}{c}\text { English } \\
\text { Caucasians }\end{array}$ & 205 & $77.4 \%: 22.6 \%$ & ND \\
\hline $\begin{array}{l}\text { Demer et } \\
\text { al; } 1997\end{array}$ & $\begin{array}{c}\text { German } \\
\text { Caucasians }\end{array}$ & 186 & $3.1 \%: 16.9 \%$ & ND \\
\hline $\begin{array}{l}\text { Capei et } \\
\text { al; } 2003\end{array}$ & $\begin{array}{c}\text { Italian } \\
\text { Caucasians }\end{array}$ & 140 & $91 \%: 9 \%$ & $93 \% \%: 7 \%$ \\
\hline $\begin{array}{l}\text { Riah et al; } \\
2004\end{array}$ & $\begin{array}{c}\text { Australian } \\
\text { Caucasians }\end{array}$ & 140 & $86 \%: 14 \%$ & ND \\
\hline
\end{tabular}
study and other ethnics)
ND; Not Done

Table III: Allele frequencies of TNF- $\alpha$ in healthy control (This

\begin{tabular}{|c|c|c|c|c|}
\hline & Ethnicity & $\mathbf{N}$ & $\begin{array}{l}-308 \\
\text { G: A }\end{array}$ & $\begin{array}{l}-238 \\
\text { G: A }\end{array}$ \\
\hline This study & Japanese & 130 & $98 \%: 2 \%$ & $99 \%: 1 \%$ \\
\hline $\begin{array}{l}\text { Higuchi et } \\
\text { al; } 1998\end{array}$ & Japanese & 575 & $98.3 \%: 1.7 \%$ & $98 \%: 2 \%$ \\
\hline $\begin{array}{l}\text { Hashimoto } \\
\text { et al; } 2004\end{array}$ & Japanese & 458 & $99.2 \%: 0.8 \%$ & ND \\
\hline $\begin{array}{l}\text { Tsunemi } \\
\text { et al: } 2003\end{array}$ & Japanese & 96 & $97.9 \%: 2.1 \%$ & $99 \%: 1 \%$ \\
\hline $\begin{array}{l}\text { Wu et al; } \\
2002\end{array}$ & Taiwanese & 220 & $88 \%: 12 \%$ & $98 \%: 2 \%$ \\
\hline $\begin{array}{l}\text { Jang et al; } \\
2001\end{array}$ & Korean & 92 & $92.9 \%: 7.1 \%$ & $96.2 \%: 3.8 \%$ \\
\hline $\begin{array}{l}\text { Park et al; } \\
2002\end{array}$ & Korean & 190 & $84.7 \%: 15.3 \%$ & ND \\
\hline $\begin{array}{l}\text { Duan et al; } \\
2004\end{array}$ & Chinese & 632 & $92.9 \%: 7.1 \%$ & ND \\
\hline $\begin{array}{l}\text { El-Omar } \\
\text { et al; } 2003\end{array}$ & USA & 210 & $84.8 \%: 15.2 \%$ & ND \\
\hline $\begin{array}{l}\text { Reynard et } \\
\text { al; } 2000\end{array}$ & $\begin{array}{c}\text { U.K. } \\
\text { Caucasians }\end{array}$ & 76 & $78.3 \%: 21.7 \%$ & ND \\
\hline $\begin{array}{l}\text { Kurzawski } \\
\text { et al; } 2005\end{array}$ & $\begin{array}{c}\text { Polish } \\
\text { Caucasians }\end{array}$ & 205 & $85.1 \%: 14.9 \%$ & ND \\
\hline $\begin{array}{l}\text { Kurzawski } \\
\text { et al; } 2005\end{array}$ & $\begin{array}{c}\text { English } \\
\text { Caucasians }\end{array}$ & 205 & $77.4 \%: 22.6 \%$ & ND \\
\hline $\begin{array}{l}\text { Demer et } \\
\text { al; } 1997\end{array}$ & $\begin{array}{c}\text { German } \\
\text { Caucasians }\end{array}$ & 186 & $3.1 \%: 16.9 \%$ & ND \\
\hline $\begin{array}{l}\text { Capei et } \\
\mathrm{al} ; 2003\end{array}$ & $\begin{array}{c}\text { Italian } \\
\text { Caucasians }\end{array}$ & 140 & $91 \%: 9 \%$ & $93 \% \%: 7 \%$ \\
\hline $\begin{array}{l}\text { Riah et al; } \\
2004\end{array}$ & $\begin{array}{c}\text { Australian } \\
\text { Caucasians }\end{array}$ & 140 & $86 \%: 14 \%$ & ND \\
\hline
\end{tabular}
study and other ethnics)

ND; Not Done

The frequency of $\mathrm{TNF} \alpha-308$ polymorphism was similar to those of others' data except data from USA. ${ }^{12} \mathrm{TNF} \alpha-308 \mathrm{~A}$ was more frequent in USA patients than in Japanese (table IV). TNF $\alpha-238$ polymorphism showed similar distribution compared to other Asian studies. 
Polymorphisms in GC with or without H. Pylori infection: TNF $\alpha-238 \mathrm{GG}$ genotype was more frequent in GC patients with $\mathrm{H}$. pylori infection than $\mathrm{TNF} \alpha-$ $238 \mathrm{GA}$ or AA ( $93 \%$ vs $50 \%, p=0.036)$ (table V).

Table V: TNF $\alpha$-238 Genotype distribution in gastric cancer with or without Helicobactor Pylori infection

\begin{tabular}{cccc}
\hline & GG & $\begin{array}{c}\text { GA or } \\
\text { AA }\end{array}$ & $p$-value \\
\hline $\begin{array}{c}\text { H. Pylori positive Gastric } \\
\text { carcinoma }\end{array}$ & 96 & 2 & \\
$\begin{array}{c}\text { H. Pylori negative Gastric } \\
\text { Carcinoma }\end{array}$ & 27 & 2 & 0.036 \\
\hline
\end{tabular}

$p$-value reached from Fisher's exact test

TNFa-238GG genotype is more frequent in H. Pylori positive Gastric carcinoma

\section{Discussion}

A total of $130 \mathrm{GC}$ patients and 103 healthy controls were examined in this study. The distribution of TNF$\alpha$ polymorphisms was compared between GC patients and healthy control. Among the cytokines;IL10 and TNF-aplay an important role inmalignancies. ${ }^{13} \mathrm{TNF}-$ $\alpha$ polymorphisms have been correlatedwith outcomes of inflammatorydiseases and malignancies. ${ }^{14}$ Atrophic gastritis and gastric carcinogenesis are caused by Helicobacter pylori. Furthermore, the combinedgenotype for highTNF- $\alpha$ production has beenassociated with the severityof graft-rejection episodes followingorgan transplantation. ${ }^{15}$ Therefore, it was important to investigate whether these polymorphisms arelinked to $\mathrm{H}$. pylori related GC.

TNF- apolymorphisms and ethnicity:The distribution of TNF- $\alpha$ polymorphism in the controls of our study was similar to other study of Japanese or Asian, but was quite different from Caucasians (table III \& IV). The frequency of -308A is almost absent in Japanese, whereas it was observed in 9-22\% in Caucasians.

TNF- $\alpha$ polymorphisms and cancer risks:There were several reports regarding TNF- $\alpha$ polymorphisms and GC risk reported that TNF $\alpha-308 \mathrm{~A}$ was at increased risk for GC. ${ }^{16}$ Some reported no relation between TNF$\alpha$ polymorphisms and GC risk. ${ }^{17-20}$ In the present study, TNF $\alpha-308 \mathrm{~A}$ wasnot related to overall incidence of GC. As for the infection of causative organisms, there was no significant correlation identified in the present study. On the other hand, as for the H. pylori infection TNF $\alpha-238 \mathrm{G}$ is related to higher frequency of $\mathrm{H}$. pylori infection. Both TNF- 308Aand-238G are high TNF- $\alpha$ producer allele and TNF-238G related to $H$. pylori infection.Mucosal production of TNF- $\alpha$ increased in $\mathrm{H}$. pylori associated gastritis. ${ }^{21-22}$ Mucosal high TNF- $\alpha$ level might show more severe inflammatory response and cause more severe and prolonged inflammation. Thus, chronic inflammation and pro-inflammatory genotype might play an important role in carcinogenesis of GC.

\section{Conclusion}

TNF- $\alpha$ promoter polymorphisms influence on GC risk. High TNF producer allele is related to increased risks. TNF- $\alpha$ polymorphism might strengthen carcinogenesis through chronic inflammation of $\mathrm{H}$. pylori. The ethnic and regional factors should be considered in the study for genetic polymorphisms and its significance should be carefully analysed according to the study population.

\section{Conflict of interest: None}

\section{Acknowledgements}

This work was supported by the Japanese Goverment research grant. Also, I would like to acknowledge the financial assistance provided by the Tonen International Scholarship Foundation and Sato International Scholarship Foundation for conducting the study.

\section{References}

1. You WC, Zhang L, Gail MH. Gastric dysplasia and gastric cancer:Helicobacter pylori, serum vitamin C and other risk factors. J Natl Cancer Ints. 2000; 92:1607-12.

2. Peek RM, Blaster MJ. Helicobacter pylori and gastrointestinal tract adenocarcinomas. Nat Rev Cancer. 2002; 2:28-37.

3. Gonzalez CA, Sala N, Capella G. Genetic susceptibility and gastric cancer risk. Int J Cancer.2002;100:249-60.

4. Demer J, Porzsolt F, Ramisch S, Schmidt D, Schmid M, Messer G. Polymorphism of the tumor necrosis factor-alpha and lymphotoxin-alpha genes in chronic lymphocytic leukaemia. British J Immunol 1997; 97: 107-12.

5. Wu WS, McClain KL. DNA polymorphisms and mutations of the tumor necrosis factor alpha (TNF alpha) in Langerhans cell histiocytosis (LCH). J Interferon Cytokine Res. 1997;17: 631-35.

6. Wilson AG, Symons JA, McDowell TL, McDevitt HO, Duff GW. Effects of polymorphism in the tumor necrosis factor- $\alpha$ promoter on transcriptional activation. Proc Natl Acad Sci. USA, 1997; 94:3195-99.

7. Huizinga Tom WJ, Westerndrop Rudi GJ, Bollen Edward LEM, Keijsers V, Brinkman Brigitta MN, Langerhans Jan AM, Breedveld FC, Verweij CL, Gaer L van de, Dams L, Crusius BA, Gonzalez AG, Oosten BW van, Polman $\mathrm{CH}$, Pena AS. TNF-alpha promoter polymorphisms, production and susceptibility to multiple sclerosis in different groups of patients. J Neuroimmunol. 1997; 72:149-53. 
8. The Japanese Reasearch Society for Gastric Cancer. Japanese classification of gastric carcinoma. First English Ed. Tokyo: Kanehara; 1995.

9. Lauren P. The two histological main types of gastric carcinoma: Diffuse and so-called intestinal-type carcinoma: an attempt to a histoclinical classification.Acta Pathol Microbiol Scand 1965; 64:31-49.

10. Clayton CL, Kleanthous H, Coats PJ, Morgan DD, Tabaqchali S. Sensitive detection of Helicobacter pylori by using polymerase chain reaction. J Clin Microbiol. 1992; 30:192-200.

11. Wilson AG, di Giovine FS, Blakemore AI, Duff GW. Single base polymophism in the human tumor necrosis factor alpha (TNF alpha) gene detectable by NcoI restriction of PCR product. Hum Mol Genet 1992; 1:353.

12. EL-Omar EM, Rabkin CS, Gammon MD, Vaughan TL, Risch HA, Schoenberg JB, Stanford JL, Mayne ST, Goedert J, Blot WJ, Fraumeni JF, Chow WH. Increased risk of non-cardia gastric cancer association with proinflammatory cytokine gene polymorphisms. Gastroenterol. 2003; 124:1193-1201.

13. TaoJ, Wasik MA. Epstein-Barr virus-associated polymorphic lymphoproliferative disorders occurring in nontransplant setting. Lab Invest. 2001; 81: 429-37.

14. Bernert H, Sekikawa K, Radcliffe RA, Iraqi F, You Y, Malkinson AM. TNFa and IL-10 deficiencies have contrasting effects on lung tumor susceptibility: Gender-dependent modulation of IL-10 haploinsufficiency. Mol Carcinogenesis. 2003; 38:117-23.

15. Turner D, Grantet SC, Yonan N. Cytokine gene polymorphism and heart transplant rejection. Transplant. 1997; 64:776-79.
16. Machado JC, Figueiredo Ceu, Canedo P, Pharoah Paul Carvalho R, Nabais S, Alves CS, Campos ML, Doorn L-J V, Calda C, Seruca R, Carneiro F, Sobrinho-Simoes M. A proinflammatory genetic profile increases the risk for chronic atrophic gastritis and gastric carcinoma. Gastroenterol. 2003; 125:364-71.

17. Jang W, Yang Y-II, Yea SS, Lee YJ, Chun JH, Kim HI, Kim MS, Paik KH. The -238 tumor necrosis factor-alpha promoter polymorphism is associated with decreased susceptibility to cancers. Cancer Lett. 2001; 166: 41-46.

18. Wu MS, Wu CY, Chen CJ, Lin MT, Shun CT, Lin JT. Interleukin-10 genotypes associate with the risk of gastric carcinoma in Taiwanese Chinese. Int $\mathbf{J}$ Cancer. 2003; 104: 617-23.

19. Lee JY, Kim HY, Kim KH, Kim SM, Jang MK, Park JY, Lee JH, Kim JH, Yoo JY. Association of polymorphisms of IL-10 and TNF-A genes with gastric cancer in Korea. Cancer Lett. 2005; 225:207-14.

20. Perri F, Piepoli A, Bonvcini C, Gentile A, Quitadamo M, Candia M Di, Cotugno R, Cattaneo F, Zagari M.R, Ricciardiello L, Gennarelli M, Bazzoli F, Ranzani G.N, Andriulli A. Cytokine gene polymorphisms in gastric cancer patients from two Italian areas at high and low cancer prevalence. Cytokine. 2005; 30:293-302.

21. Crabtree JE, Shallcross TM, Heatley RV, Wyatt JI. Mucosal tumor necrosis factor-alpha and interleukin-6 in patients with Helicobacter pylori associated gastritis. Gut. 1991; 32:1473-77

22. Noach LA, Bosma NB, Jansen J, Hoek FJ, van Deventer SJ, Tytgat GN. Mucosal tumor necrosis factor-alpha, interleukin-1 $\beta$, and interleukin-8 production in patients with Helicobacter pylori infection. Scand J Gastroenterol. 1994; 29:425-29. 